\title{
SYNTHESIS, CHARACTERIZATION, LUMINESCENCE AND DNA BINDING PROPERTIES OF Ln (III)-SCHIFF BASE FAMILY
}

\author{
S. VIDYA SAGAR BABUं, K.S.V.KRISHNA RAO§* YONG ILL LEE** \\ † Department of Chemistry, Sri Krishnadevaraya University, Aanantapuramu-515 003, India. \\ $\S$ Department of Chemistry, Yogi Vemana University, Kadapa-516 003, India. \\ *Department of Chemistry, Changwon National University, Changwon, South Korea.
}

\begin{abstract}
Pentadentate Schiff base ligand(N,N-bis(2-hydroxy-1-naphthylidene) diethylenetriamine) $\left(\mathrm{H}_{2} \mathrm{~L}\right)$ that exhibits a $\mathrm{N}_{3} \mathrm{O}_{2}$ donor set. Five rare earth complexes lanthanide (III), praseodymium (III), neodymium(III), samarium(III)and europium (III) complexes are synthesized and characterized based on elemental analyses, molar conductance, infrared, ultraviolet, thermo gravimetric, X-ray powder diffraction and mass spectral studies. Molar conductivity data suggests that the complexes are 1:1 electrolytics. Infrared spectral data suggest that the ligand binds through two naptholic oxygen atoms, two azomethine nitrogen atoms and one primary amine. IR studies reveal that the complexes contain both coordinating and ionic nitrate ligands. Thermal decomposition studies indicate the presence of two nitrate ions and two water molecules in the inner coordination sphere. $\mathrm{Eu}^{3+}$ and $\mathrm{Sm}^{3+}$ complexes exhibit luminescence properties. Further, the binding properties of these complexes with calf-thymus DNA have been investigated using absorption spectrophotometry.
\end{abstract}

Keywords: Rare earth complexes, X-ray powder diffraction, Luminescence, DNA binding.

\section{INTRODUCTION}

Recently, lanthanide ions, Ln(III) with organic ligands have attracted much attention because of their unique luminescence and magnetic properties ${ }^{1}$. Due to these properties, the use of lanthanide-based probes are becoming more common in a wide variety of photonic applications such as luminescence spectroscopy, planar waveguide amplifiers ${ }^{2-5}$, light-emitting diodes LEDs $^{6}$, plastic lasers and bio-inspired luminescence probes ${ }^{7-10}$. Among Ln(III) ions, $\mathrm{Eu}^{3+}$ and $\mathrm{Sm}^{3+}$ have intense long-lived and line-like emission in the visible region that enables them to be promising applications from display devices to biological assays ${ }^{11}$. Unfortunately, the low extinction coefficients of free lanthanide ions result in very inefficient light absorption, which makes direct excitation impossible. However, the luminescence properties of lanthanides can be improved by means of organic ligands containing suitable chromophores coordinated to the lanthanides ${ }^{12}$. This luminescent ligand acts as antenna by efficiently absorbing light in the UV region and transforming the absorbed energy to the emitted level of the lanthanide ion. Moreover, the ligand can protect the lanthanide from vibrational coupling that may quench the luminescence ${ }^{13}$. In addition to the spectroscopic and magnetic properties, the biological activities of the lanthanide complexes such as antitumor, antimicrobial, antivirus, anticoagulant action, from arteriosclerosis, luminescent bio probes, etc., have been investigated in the last few years ${ }^{14,15}$. This work focuses on the use of $\mathrm{H}_{2} \mathrm{~L}$ ligand which have selective ability to coordinate to lanthanide ions thus protect them from deactivation caused by interaction with solvent molecules and enhance their luminescence by providing proper conjugate absorption groups suitable for energy transfer. Due to the importance of the Schiff base ligands in the various fields of separation and biomedical science ${ }^{16-19}$, authors have investigated $\mathrm{La}(\mathrm{III}), \operatorname{Pr}(\mathrm{III}), \mathrm{Nd}$ (III), Sm (III), Eu(III) complexes with (N,N-bis (2-hydroxy-1-naphthylidene) diethylenetriamine) ligand $\left(\mathrm{H}_{2} \mathrm{~L}\right)$. The coordination behavior has been investigated by correlating with the luminescence properties of these complexes in solutions at room temperature. In addition, the binding properties of these complexes with CT-DNA have been investigated using absorption spectrophotometry.

\section{EXPERIMENTAL}

\subsection{Materials and methods}

Lanthanide salts, $\left\{\left[\mathrm{Ln}\left(\mathrm{NO}_{3}\right)_{3} 6 \mathrm{H}_{2} \mathrm{O}\right] \mathrm{Ln}=\mathrm{La}, \mathrm{Pr}, \mathrm{Nd}, \mathrm{Sm} \mathrm{Eu}\right\}, 2-\mathrm{Hydroxy}-$ 1-napthaladehyde and diethylenetriamine were purchased from Sigma Aldrich. All other solvents and reagents used were of analytical grade. The metal content of the complexes was determined by titration with EDTA $^{20}$ using xylenol oranges as an indicator. Elemental analysis was carried out on a Perkin-Elmer $2400 \mathrm{CHN}$ elemental analyzer. Molar conductivity was measured in dimethyl formamide(DMF) solution, concentration of $10^{-4} \mathrm{M}$, at $25{ }^{\circ} \mathrm{C}$ using ELICO conductivity meter equipped with CM162 conductivity cell. Infrared spectra were recorded on a Perkin-Elmer FT-IR model 100 spectrophotometer in the region of $4000-400 \mathrm{~cm}^{-1}$ using $\mathrm{KBr}$ pellets. The spectra were recorded at room temperature with $2 \mathrm{~cm}^{-1}$ resolution. UV-visible spectra were recorded in DMF solution, concentration of $10^{-5} \mathrm{M}$, at $25^{\circ} \mathrm{C}$ using a UV Lamda 50 Perkin-Elmer UV-visible spectrophotometer. Fluorescence spectra (scanned from 200 to $900 \mathrm{~nm}$, with a spectral resolution of $0.2 \mathrm{~nm}$, slit widths $\sim 2.5 \mathrm{~nm}$ ) were recorded instrument model Perkin Elmer precisely LS-55 fluorescence spectrophotometer with $1 \mathrm{~cm}$ quartz cell at room temperature. The light source and detectors were $450 \mathrm{~W}$ xenon lamp and R955 photomultiplier tube, respectively. The thermal analysis was performed on a Perkin-Elmer Spectrum 2, Pyris STA 6000 thermo balance analyzer operating at a heating rate of $10^{\circ} \mathrm{C} / \mathrm{min}$ in the range of ambient temperature up to $900^{\circ} \mathrm{C}$ under $\mathrm{N}_{2}$. X-ray diffractometer (XRD) Philips: PW1830. Electron ionization-mass spectrometer, model: AUTOSPEC-M, Micromass, UK.

\subsection{DNA binding experiments}

A solution of CT-DNA in $0.5 \mathrm{mM} \mathrm{NaCl} / 5 \mathrm{mM}$ Tris- $\mathrm{HCl}(\mathrm{pH} 7.0)$ gave a ratio of UV absorbance at 260 and $280 \mathrm{~nm}\left(\mathrm{~A}_{260} / \mathrm{A}_{280}\right)$ of 1.8-1.9, indicating that the DNA was sufficiently free of proteins ${ }^{21}$. A concentrated stock solution of DNA was prepared in $5 \mathrm{mM}$ Tris- $\mathrm{HCl} / 50 \mathrm{mM} \mathrm{NaCl}$ in water at $\mathrm{pH} 7$ and the concentration of CT-DNA was determined per nucleotide by taking the absorption coefficient $\left(6,600 \mathrm{dm}^{3} \mathrm{~mol}^{-1} \mathrm{~cm}^{-1}\right)$ at $260 \mathrm{~nm}^{22}$. Stock solutions were stored at $4{ }^{\circ} \mathrm{C}$ and were used after no more than 4 days. Doubly distilled water was used to prepare buffer solutions. Solutions were prepared by mixing the complex and CT-DNA in DMF medium. After equilibrium was reached (ca.5 min) the spectra were recorded against an analogous blank solution containing the same concentration of DNA. The data were then fitted into Eq.1 to obtain the intrinsic binding constant $\left(K_{\mathrm{b}}\right)^{23}$.

$$
[\mathrm{DNA}] /\left(\varepsilon_{\mathrm{A}}-\varepsilon_{\mathrm{B}}\right)=[\mathrm{DNA}] /\left(\varepsilon_{\mathrm{B}}-\varepsilon_{\mathrm{F}}\right)+1 / \mathrm{K}\left(\varepsilon_{\mathrm{B}}-\varepsilon_{\mathrm{F}}\right) \ldots(1)
$$

where $\varepsilon_{\mathrm{A}}, \varepsilon_{\mathrm{B}}$ and $\varepsilon_{\mathrm{F}}$ correspond to the apparent, bound and free metal complex extinction coefficients, respectively. A plot of [DNA] $/\left(\varepsilon_{\mathrm{A}}-\varepsilon_{\mathrm{F}}\right)$ versus [DNA] gave a slope of $1 /\left(\varepsilon_{\mathrm{B}}-\varepsilon_{\mathrm{F}}\right)$ and a Y-intercept equal to $1 / K_{\mathrm{b}}\left(\varepsilon_{\mathrm{B}}-\varepsilon_{\mathrm{F}}\right) ; K_{\mathrm{b}}$ is the ratio to the $\mathrm{Y}$-intercept.

\subsection{Synthesis of Schiff base ligand $\left(\mathrm{H}_{2} \mathrm{~L}\right)$}

The Schiff base ligand $\mathrm{H}_{2} \mathrm{~L}$ was prepared $^{24}$ by mixing 2-hydroxy1-napthaladehyde $(1.72 \mathrm{~g} ; 10 \mathrm{~m} \mathrm{~mol})$ in $20 \mathrm{ml}$ of hot methanol with diethylenetriamine $(0.54 \mathrm{ml} ; 5 \mathrm{mmol})$ in $10 \mathrm{ml}$ of methanol. The resulting reaction mixture was taken in a $100 \mathrm{ml}$ round bottom flask and heated under reflux on water bath for $1 \mathrm{~h}$. On cooling the reaction mixture, a crude yellow product was obtained. Then, the product was collected by filtration, washed with cold ethanol and dried. Finally, the product was recrystallized from hot ethanol. Yield: $60 \%$; m.p. $253{ }^{\circ} \mathrm{C}$.

\subsection{Synthesis of $\operatorname{Ln}(I I)$ complexes}

A $0.350 \mathrm{~m}$ mole $(0.143 \mathrm{~g})$ of $\mathrm{H}_{2}$ Lwas dissolved in $20 \mathrm{ml}$ of chloroform ${ }^{25}$. To this solution, a solution of $\mathrm{Ln}\left(\mathrm{NO}_{3}\right)_{3} \cdot 6 \mathrm{H}_{2} \mathrm{O}$ [ $\left.\mathrm{Ln}=\mathrm{La}, \mathrm{Pr}, \mathrm{Nd}, \mathrm{Sm}, \mathrm{Eu}\right](0.350$ 
$\mathrm{m}$ mole) in $10 \mathrm{ml}$ acetonitrile was added drop wise. The reaction mixture was stirred for $4 \mathrm{~h}$, and the yellow precipitate formed was filtered, washed with $\mathrm{CCl}$ and dried in vacuo. The complex was recrystallized by slow diffusion of diethyl ether into a methanol solution of the complex. Yield: 70\%.

\section{RESULTS AND DISCUSSION}

In the present investigations, $\mathrm{Ln}(\mathrm{III})$ complexes of Schiff base ligand $\left(\mathrm{H}_{2} \mathrm{~L}\right)$ were synthesized and characterized based on physico-chemical and spectral techniques. The ligand $\left(\mathrm{H}_{2} \mathrm{~L}\right)$ was synthesized by a conventional one-step condensation of 2-hydroxy-1-napthaladehyde and diethylenetriamine. All the complexes were synthesized by reacting $\left[\mathrm{Ln}\left(\mathrm{NO}_{3}\right)_{3} \cdot \mathrm{XH}_{2} \mathrm{O}\right]$ (where $\mathrm{Ln}=\mathrm{La}$

$\mathrm{Pr}, \mathrm{Nd}, \mathrm{Sm}, \mathrm{Eu}$ ) with the ligand $\mathrm{H}_{2} \mathrm{~L}$ yielded a series of complexes correspond to the formula of $\left[\mathrm{LnH}_{2} \mathrm{~L}\left(\mathrm{NO}_{3}\right)_{2} 2 \mathrm{H}_{2} \mathrm{O}\right] \mathrm{NO}_{3} \cdot 2 \mathrm{H}_{2} \mathrm{O}$. All complexes are stable at room temperature, non-hygroscopic, insoluble in water and diethyl ether, but slightly soluble in methanol, ethanol, ethyl acetate, chloroform, benzene and readily soluble in dimethylforma amide and DMSO. The elemental analysis, compound formula, weight, yield $\%$, and molar conductivity data of the complexes are given in Table 1.

3.1. Molar conductance

Molar conductivity values for all complexes in DMF solution at $25^{\circ} \mathrm{C}$, tabulated in Table 1, are in the range of $76-117 \Omega^{-1} \mathrm{~cm}^{2} \mathrm{~mol}^{-1}$ as reported for $1: 1$ electrolytes ${ }^{26}$. The values suggest ionic nature of the complexes.

\subsection{Infrared spectroscopy}

Important IR spectral bands Fig.1 data of the samarium complex are present in Table 2. The comparison of the IR spectra of the free ligand and $\left[\mathrm{LnH} \mathrm{L}_{2}\left(\mathrm{NO}_{3}\right)_{2} 2 \mathrm{H}_{2} \mathrm{O}\right] \mathrm{NO}_{3} .2 \mathrm{H}_{2} \mathrm{O}$ complexes. The ligand (N,N-bis (2-hydroxy1-naphthylidene) diethylenetriamine) significant broad bands were obtained at $1633 \mathrm{~cm}^{-1}$ corresponding to imine $v(>\mathrm{C}=\mathrm{N}-)$ stretching frequency. Condensation of all the primary amine groups has been confirmed from the absence of the $(=\mathrm{N}-\mathrm{H})$ stretching bands in the region $3150-3450 \mathrm{~cm}^{-1}{ }^{27}$. The spectra of all the complexes contain strong peaks characteristic of $v(>\mathrm{C}=\mathrm{N}-$ bands, indicating the complexation of the lanthanide ions. Indeed, upon coordination to the metal center, the imine
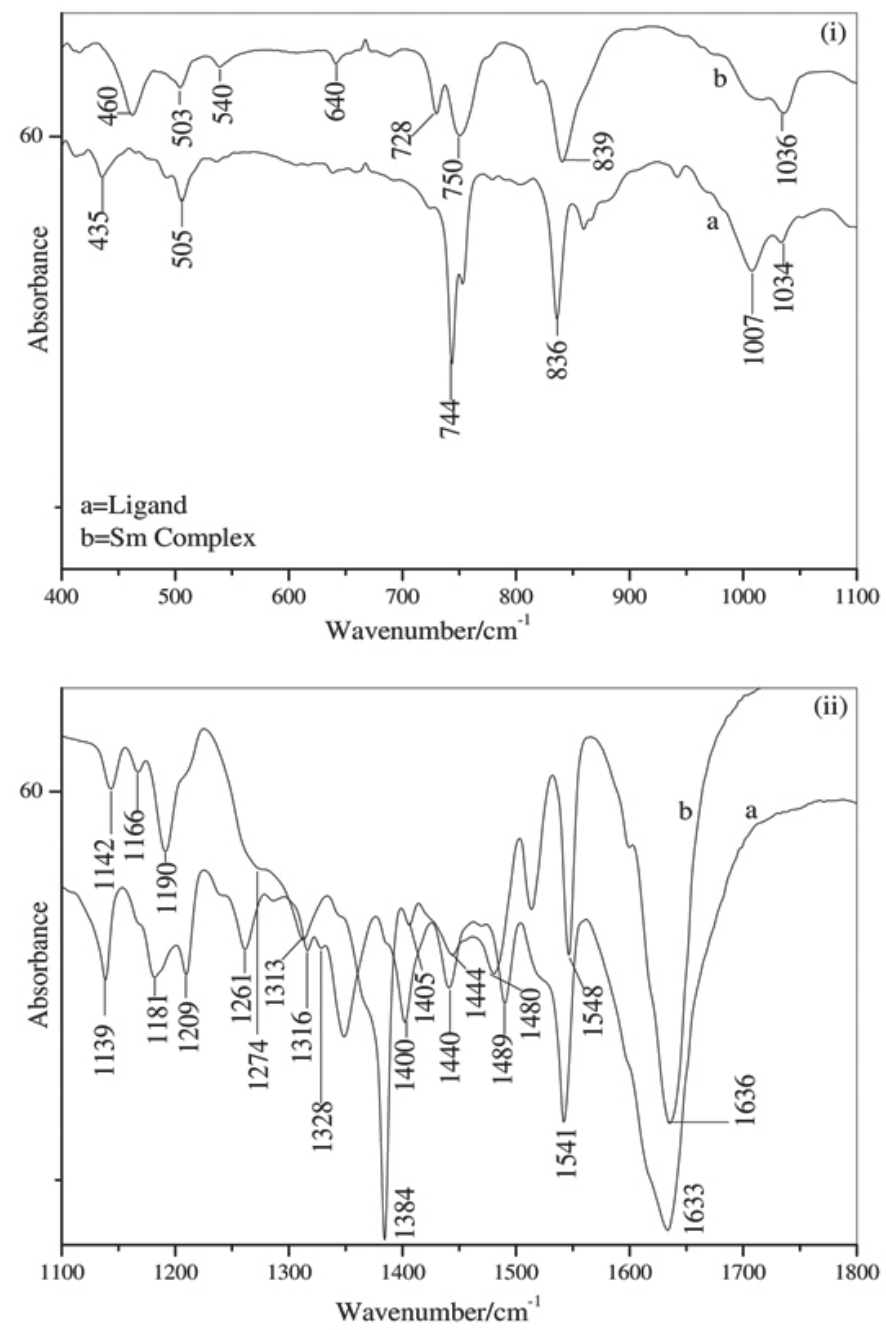
and ii).

Fig1. Infrared spectra in the $1800-400 \mathrm{~cm}^{-1}$ region for the Sm complex (i 
Table 1. Elemental analytical data and molar conductance values for the Ln complexes.

\begin{tabular}{|c|c|c|c|c|c|c|}
\hline Compound & F.wt & $\mathrm{C}(\%)$ found(Calc. $)$ & $\begin{array}{c}\mathrm{H}(\%) \\
\text { found(Calc.) }\end{array}$ & $\begin{array}{c}\mathrm{N}(\%) \\
\text { found(Calc.) }\end{array}$ & Yield(\%) & $\wedge_{\mathrm{m}}\left(\Omega^{-1} \mathrm{~cm}^{2} \mathrm{~mol}^{-1}\right)$ \\
\hline Ligand $\mathrm{H}_{2} \mathrm{~L}$ & 412.0 & $75.92(75.91)$ & $6.12(6.08)$ & $10.24(10.21)$ & 60 & - \\
\hline$\left[\mathrm{LaH}_{2} \mathrm{~L}\left(\mathrm{NO}_{3}\right)_{2} 2 \mathrm{H}_{2} \mathrm{O}\right] \mathrm{NO}_{3} \cdot 2 \mathrm{H}_{2} \mathrm{O}$ & 807.9 & $35.99(38.61)$ & $2.88(4.08)$ & $9.97(10.39)$ & 50 & 76.68 \\
\hline$\left[\mathrm{PrH}_{2} \mathrm{~L}\left(\mathrm{NO}_{3}\right)_{2} 2 \mathrm{H}_{2} \mathrm{O}\right] \mathrm{NO}_{3} \cdot 2 \mathrm{H}_{2} \mathrm{O}$ & 809.9 & $35.96(38.52)$ & $2.87(4.07)$ & $9.96(10.37)$ & 62 & 99.54 \\
\hline$\left[\mathrm{NdH}_{2} \mathrm{~L}\left(\mathrm{NO}_{3}\right)_{2} 2 \mathrm{H}_{2} \mathrm{O}\right] \mathrm{NO}_{3} \cdot 2 \mathrm{H}_{2} \mathrm{O}$ & 812.5 & $35.81(38.37)$ & $2.85(4.05)$ & $9.95(10.33)$ & 65 & 116.52 \\
\hline$\left[\mathrm{SmH}_{2} \mathrm{~L}\left(\mathrm{NO}_{3}\right)_{2} 2 \mathrm{H}_{2} \mathrm{O}\right] \mathrm{NO}_{3} \cdot 2 \mathrm{H}_{2} \mathrm{O}$ & 819.3 & $35.52(38.08)$ & $2.82(4.02)$ & $9.98(10.25)$ & 60 & 88.21 \\
\hline$\left[\mathrm{EuH}_{2} \mathrm{~L}\left(\mathrm{NO}_{3}\right)_{2} 2 \mathrm{H}_{2} \mathrm{O}\right] \mathrm{NO}_{3} \cdot 2 \mathrm{H}_{2} \mathrm{O}$ & 820.5 & $35.46(38.02)$ & $2.82(4.02)$ & $9.99(10.23)$ & 60 & 87.64 \\
\hline
\end{tabular}

(Calc.): Calculated

Table 2. Important IR bands $\left(\mathrm{cm}^{-1}\right)$ and UV-visible absorption bands for the Ln complexes.

\begin{tabular}{|c|c|c|c|c|c|c|c|c|c|c|c|c|}
\hline Complex & $\begin{array}{c}v \\
(\mathrm{O}-\mathrm{H})\end{array}$ & $\begin{array}{c}v \\
(\mathrm{C}=\mathrm{N})\end{array}$ & $\begin{array}{c}v \\
(\mathrm{Ar}- \\
\mathrm{O})\end{array}$ & $\begin{array}{c}v \\
\left(\mathrm{NO}_{3}^{-}\right)\end{array}$ & & & & & & $\begin{array}{c}v \\
(\mathrm{Ln}-\mathrm{O})\end{array}$ & $\begin{array}{c}v \\
(\mathrm{Ln}-\mathrm{N})\end{array}$ & $\lambda_{\max }(\mathrm{nm})$ \\
\hline & & & & $v_{1}$ & $v_{2}$ & $v_{3}$ & $v_{4}$ & $v_{1-4}$ & $v_{0}$ & & & \\
\hline Ligand $\mathrm{H}_{2} \mathrm{~L}$ & 3280 & 1633 & 1261 & - & - & - & - & - & - & - & - & $305^{\mathrm{a}}, 402^{\mathrm{b}}$ \\
\hline$\left[\mathrm{LaH}_{2} \mathrm{~L}\left(\mathrm{NO}_{3}\right)_{2} 2 \mathrm{H}_{2} \mathrm{O}\right] \mathrm{NO}_{3} \cdot 2 \mathrm{H}_{2} \mathrm{O}$ & 3376 & 1636 & 1272 & 1480 & 1035 & 839 & 1312 & 169 & 1384 & 641 & 460 & $307^{\mathrm{a}}, 421^{\mathrm{b}}, 362^{\mathrm{c}}$ \\
\hline$\left[\mathrm{PrH}_{2} \mathrm{~L}\left(\mathrm{NO}_{3}\right)_{2} 2 \mathrm{H}_{2} \mathrm{O}\right] \mathrm{NO}_{3} \cdot 2 \mathrm{H}_{2} \mathrm{O}$ & 3378 & 1638 & 1274 & 1480 & 1036 & 840 & 1313 & 167 & 1384 & 642 & 462 & $307^{\mathrm{a}}, 421^{\mathrm{b}}, 362^{\mathrm{c}}$ \\
\hline$\left[\mathrm{NdH}_{2} \mathrm{~L}\left(\mathrm{NO}_{3}\right)_{2} 2 \mathrm{H}_{2} \mathrm{O}\right] \mathrm{NO}_{3} .2 \mathrm{H}_{2} \mathrm{O}$ & 3376 & 1636 & 1272 & 1480 & 1036 & 839 & 1313 & 167 & 1384 & 642 & 463 & $307^{\mathrm{a}}, 421^{\mathrm{b}}, 362^{\mathrm{c}}$ \\
\hline$\left[\mathrm{SmH}_{2} \mathrm{~L}\left(\mathrm{NO}_{3}\right)_{2} 2 \mathrm{H}_{2} \mathrm{O}\right] \mathrm{NO}_{3} \cdot 2 \mathrm{H}_{2} \mathrm{O}$ & 3378 & 1636 & 1274 & 1480 & 1036 & 839 & 1313 & 167 & 1384 & 640 & 460 & $307^{\mathrm{a}}, 421^{\mathrm{b}}, 362^{\mathrm{c}}$ \\
\hline$\left[\mathrm{EuH}_{2} \mathrm{~L}\left(\mathrm{NO}_{3}\right)_{2} 2 \mathrm{H}_{2} \mathrm{O}\right] \mathrm{NO}_{3} \cdot 2 \mathrm{H}_{2} \mathrm{O}$ & 3378 & 1635 & 1273 & 1480 & 1037 & 839 & 1313 & 167 & 1384 & 643 & 461 & $307^{\mathrm{a}}, 407^{\mathrm{b}}, 381^{\mathrm{c}}$ \\
\hline
\end{tabular}

$\mathrm{a}=\pi \rightarrow \pi^{*} ; \mathrm{b}=\mathrm{n} \rightarrow \pi^{*} ; \mathrm{c}=\mathrm{LMCT}$

$v(>\mathrm{C}=\mathrm{N}-)$ stretching frequency in the IR spectra dropped from 1633 $\mathrm{cm}^{-1}$ in the free ligand, to $1636,1638,1636,1636$ and $1635 \mathrm{~cm}^{-1}$ in the related $\mathrm{La}(\mathrm{III}), \operatorname{Pr}(\mathrm{III}), \mathrm{Nd}(\mathrm{III}), \mathrm{Sm}(\mathrm{III})$ and $\mathrm{Eu}(\mathrm{III})$ complexes. In the $\mathrm{H}_{2} \mathrm{~L}$ ligand, the phenolic $v(\mathrm{O}-\mathrm{H})$ vibration band appeared at $3280 \mathrm{~cm}^{-1}$ while the coordinated vibration mode is shifted towards higher frequency region $3376-3378 \mathrm{~cm}^{-1}$ that was due to the intramolecular hydrogen bonds of free ligand. The staying of $v(\mathrm{O}-\mathrm{H})$ in the complexes indicates that the phenolic $\mathrm{O}-\mathrm{H}$ oxygen is coordinated to the metal ion without deprotonation. The bands near $1600 \mathrm{~cm}^{-1}$ and 1260 $\mathrm{cm}^{-1}$ are associated with the $v(\mathrm{C}=\mathrm{N})$ and $v(\mathrm{C}-\mathrm{O})$, respectively. The stretching frequencies change in profile in the complexes as compared to those observed for the isolated ligand. All of the complexes showed very similar infrared spectra above $400 \mathrm{~cm}^{-1}$ and, therefore, far-infrared spectra were recorded $\left(400 \mathrm{~cm}^{-1}\right)$ in an attempt to assign $v(\mathrm{Ln}-\mathrm{O})$ and $v(\mathrm{Ln}-\mathrm{N})$ vibrational modes. $v(\mathrm{C}=\mathrm{N})$ and $v(\mathrm{C}-\mathrm{O})$, respectively. There is a paucity of such assignments in the literature ${ }^{28,29}$ though it appears that $v(\mathrm{Ln}-\mathrm{O})$ and $v(\mathrm{Ln}-\mathrm{N})$ might be expected in the $640-643,460-463 \mathrm{~cm}^{-1}$ region. This shift and the appearance of the band at $460-463 \mathrm{~cm}^{-1}$ which is assigned to $v(\mathrm{Ln}-\mathrm{N})$ confirm that the nitrogen of the azomethine group is coordinated to the lanthanide ions ${ }^{28}$.

The absorption bands of the coordinated nitrates $\left(C_{2 v}\right)$ were observed at about $1480 \mathrm{~cm}^{-1}\left(v_{1}\right), 1035-1037 \mathrm{~cm}^{-1}\left(v_{2}\right), 839-840 \mathrm{~cm}^{-1}\left(v_{3}\right)$, and 1312-1313 $\mathrm{cm}^{-1}\left(v_{4}\right)$. In addition, the separation of the two highest frequency bands $[\Delta v=$ $\left.v_{1}-v_{4}\right]$ is approximately 169 and $167 \mathrm{~cm}^{-1}$, and accordingly the coordinated $\mathrm{NO}_{3}^{-}$ ion in the complexes is a bidentate ligand ${ }^{29}$. The vibrational band is present at $1384 \mathrm{~cm}^{-1}\left(v_{0}\right)$ in IR spectra of complexes indicate the free of ionic nitrate $\left(D_{3 \mathrm{~h}}\right.$ symmetry), which is in agreement with the results of the conductivity experiments. Similar changes for all Ln complexation with the ligand ${ }^{30-33}$.

\subsection{UV-Visible spectroscopy of complexes}

The UV- visible absorption spectral data of the maximum absorption wavelength $\left(1_{\max }\right)$ and the corresponding band assignment for the ligand and its $\mathrm{Ln}$ (III) complexes $\left(10^{-5} \mathrm{M}\right.$ in DMF) are listed in Table 2 . The electronic spectra of ligand and its lanthanide complexes are shown in (Fig.2). The ligand $\left(\mathrm{H}_{2} \mathrm{~L}\right)$ shows three absorption bands with maxima at 305, 402 and $421 \mathrm{~nm}$. The bands at 402 and $421 \mathrm{~nm}$, are assigned to $n-\pi^{*}$ transitions of conjugation between the lone pair of electrons of $(>\mathrm{C}=\mathrm{N}-$ ) group a conjugated $\pi$ bond of the aromatic ring ${ }^{34-39}$. The third band at 305 arises from $\pi-\pi^{*}$ transition within the aromatic ring. The new absorbance band observed at $362 \mathrm{~nm}$ complexes was attributed to the electron transfer from lanthanide metal ion and the coordinated ligand i.e $\mathrm{M} \rightarrow \mathrm{L}$ charge transfer band. This change is essentially variant for each of the lanthanide complexes (La(III), $\mathrm{Pr}(\mathrm{III}), \mathrm{Nd}(\mathrm{III}), \mathrm{Sm}(\mathrm{III})$ and $\mathrm{Eu}(\mathrm{III})$ and is attributed to metal coordination by the ligand. The higher energy band in the free ligand is observed as a single band upon complexation without much shift in frequency. Based on analytical and spectral data a general structure (Fig.3) is tentatively assigned to the lanthanide complexes.

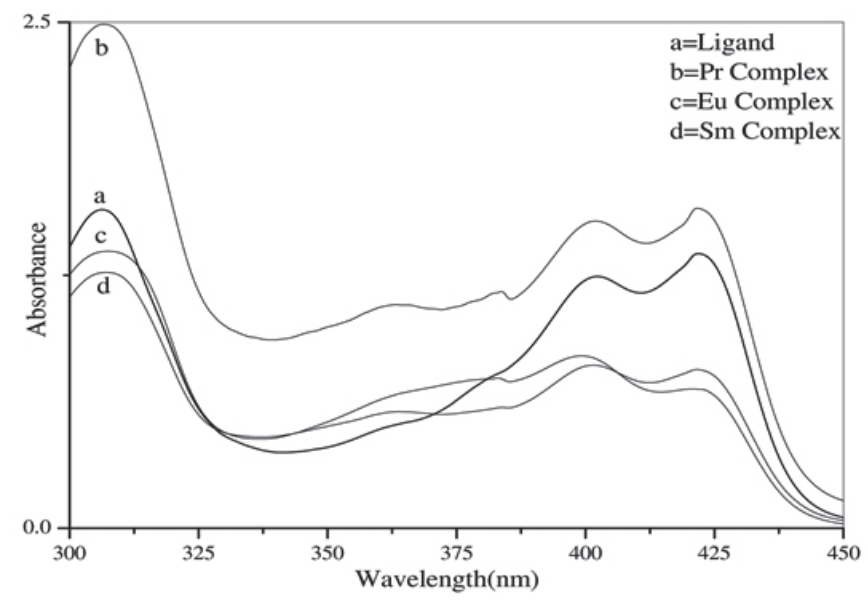

Fig 2. UV-Visible absorption spectra for the Ln complexes

\subsection{Thermogravimetric analysis}

Thermogravimetric (TGA) and differential thermogravimetric (DTA) analysis were carried out for the ligand, $\mathrm{H}_{2} \mathrm{~L}$, and its corresponding $\mathrm{Ln}$ (III) complexes within the temperature range from ambient temperature up to 900 ${ }^{\circ} \mathrm{C}$ under $\mathrm{N}_{2}$ flow. The correlation between the different decomposition steps of $\mathrm{Ln}$ (III) complexes with the corresponding weight losses are discussed in terms of the proposed formula of the $\mathrm{Ln}$ (III) complexes. TGA results showed that the ligand $\mathrm{H}_{2} \mathrm{~L}$ is thermally stable up to $240^{\circ} \mathrm{C}$ and its decomposition starts at $250^{\circ} \mathrm{C}$ and finishes at $499^{\circ} \mathrm{C}$ with one decomposition step (Supplementary Fig.S1). The TGA curve of Sm(III) complex shows (Fig.4), that the Sm(III) complex undergoes multi-stage changes. The first stage, mass loss percentage was $4.5 \%$ 
is consistent with theoretical value (4.3\%). The decomposition temperatures of these hydrates ranging between 113 to $210^{\circ} \mathrm{C}$ suggests that the presence of a water molecule in the $\mathrm{Sm}(\mathrm{III})$ complex bonded in the inner coordination sphere. The second stage of decomposition in the range 210 to $277^{\circ} \mathrm{C}$ due to loss of one nitrate ion with a weight loss of $8.2 \%$ has theoretical value $(8.0 \%)$. Third stage occurs decomposition 277 to $371^{\circ} \mathrm{C}$ could be attributed to the loss of another two inner nitrate ions with a weight loss of $16.5 \%$ is consist with theoretical value $(16.2 \%)$. The fourth step processes corresponds to the loss of the ligand molecule and formation of stable $\mathrm{Ln}_{2} \mathrm{O}_{3}$ oxide residue which occurred between 371 to $900{ }^{\circ} \mathrm{C}$.

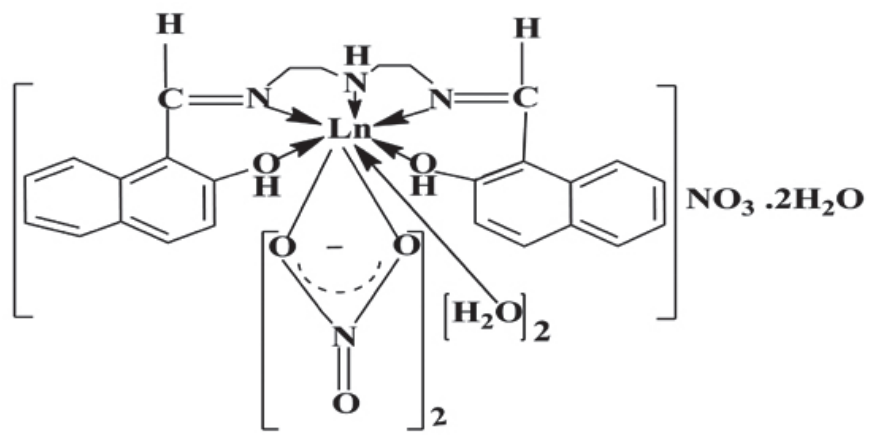

Fig 3. Proposed structure for the rare earth complexes $(\mathrm{Ln}=\mathrm{La}$, Pr, Nd, $\mathrm{Sm}$ and $\mathrm{Eu})$

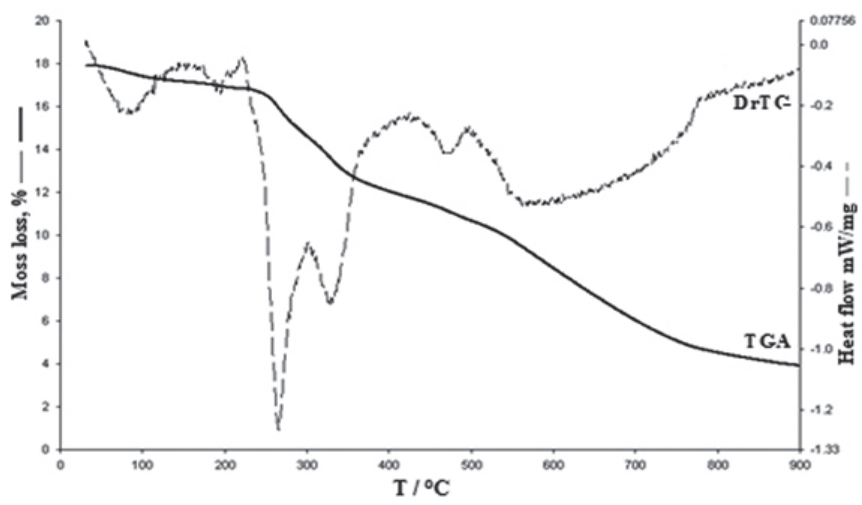

Fig.4. Differential thermal gravimetric analysis cures for the Sm complex

\subsection{X-ray powder diffraction studies}

$\mathrm{X}$-ray diffraction studies of the powder sample were carried out as it could not be possible to grow suitable crystals for complete X-ray analysis. The observed interplanar spacing values (' $d$ ' in $\mathrm{A}^{\circ}$ ), have been measured from the diffractogram of the $\left[\mathrm{SmH}_{2} \mathrm{~L}\left(\mathrm{NO}_{3}\right)_{2} 2 \mathrm{H}_{2} \mathrm{O}\right] \mathrm{NO}_{3} .2 \mathrm{H}_{2} \mathrm{O}$ complex with respect to major peaks having relative intensity at wavelength $=1.54178$ and the Millar indices, $h, k, l$ have been assigned to each $d$ value and $2 \theta$ angles are reported in Fig.5 (Supplementary Table.S1). The system belongs to 'Orthorhombic' form. The direct unit cell dimensions determined are: $a=7.9928 \mathrm{~A}^{\circ} ; b=9.0910 \mathrm{~A}^{\circ}$ $c=10.8580 \mathrm{~A}^{\circ} ; \mathrm{v}=788.9775\left(\mathrm{~A}^{\circ}\right)^{3} ; \alpha=\beta=\gamma=90^{\circ}$. Based on the experimental evidences, the average crystallite or grain size varies from 22 to $34 \mathrm{~nm}$. The system exhibits nano crystallite phase.

\subsection{Mass spectral studies}

In the present investigation, the mass spectrum of $\mathrm{H}_{2} \mathrm{~L}$ showed the formation of a molecular ion peak at m/z: 412 (sodium ion base peak m/z: 434) corresponding to the total molecular weight of the ligand(SupplementaryFig. $\mathrm{S} 2$ ). The molecular ion peak is not detected in the recorded mass spectra of the discussed $\operatorname{Ln}(\mathrm{III})$ complexes. The obtained mass spectra indicates relatively neodymium complex and exhibited a large number of peaks possibly due to extensive fragmentation.

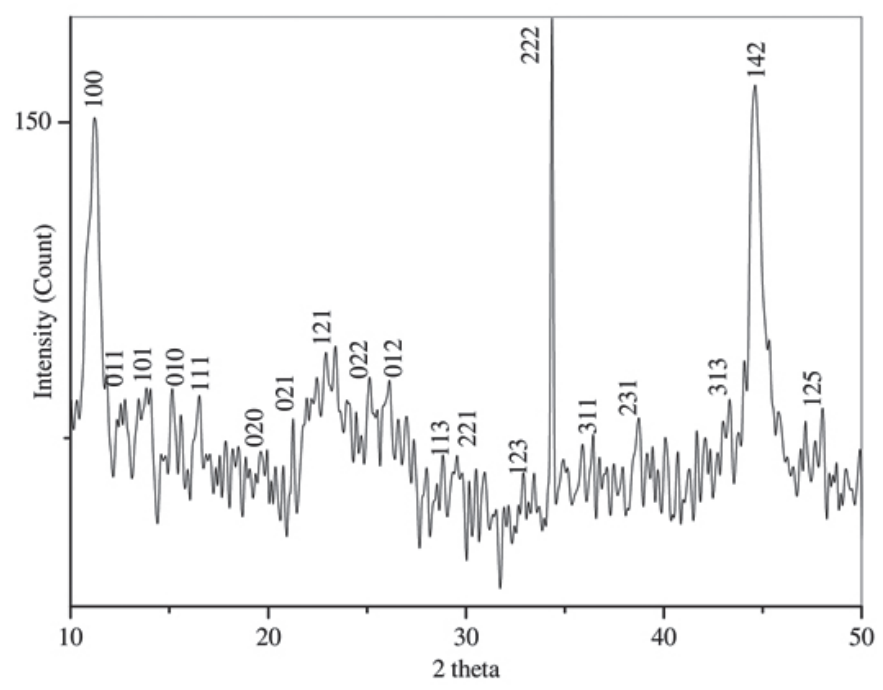

Fig.5. Powder X-ray diffraction spectrum for the Sm complex.

\subsection{Luminescence spectroscopy of complexes}

The fluorescence spectra (Fig.6) of the ligand and its $\operatorname{Ln}(\mathrm{III})$ complexes $\left(1.0 \times 10^{-5} \mathrm{M}\right.$ in DMF solution) were recorded at the room temperature. The details of the emission characteristic of the ligand and its $\operatorname{Ln}(\mathrm{III})$ complexes are listed in Table 3. The emission spectrum Fig. 6 of the free ligand $\mathrm{H}_{2} \mathrm{~L}$ exhibits broad fluorescence band centered at $363 \mathrm{~nm}$ attributed to $\pi-\pi^{*}$ transitions. Inspection of emission spectra $(\lambda=307 \mathrm{~nm})$ shown in Fig. 6 together with the data listed in Table 3 , indicate that $363 \mathrm{~nm}$ attributed to $\pi-\pi^{*}$ transitions $\mathrm{s}^{35-41}$. Inspection of $\mathrm{Eu}, \mathrm{Sm}, \mathrm{Nd}$ and $\mathrm{Pr}$ complexes exhibit the characteristic emission spectra of the $\mathrm{Ln}(\mathrm{III})$ ions respectively. This indicates that the ligand $\mathrm{H}_{2} \mathrm{~L}$ is a good chelating organic chromophore and can be used to absorb and transfer energy to the $\mathrm{Ln}(\mathrm{III})$ ions.

Under the excitation of $307 \mathrm{~nm}$ the emission spectrum of the $\mathrm{Eu}(\mathrm{III})$ complex e displays luminescence characteristic of $\mathrm{Eu}(\mathrm{III})$ emission peak in the region 610-635 nm corresponding to ${ }^{5} \mathrm{D}_{0} \rightarrow{ }^{7} \mathrm{~F}_{2}(619 \mathrm{~nm})$ transition. Samarium (III) complex $\mathbf{d}$ also emission peak in the range $610-630 \mathrm{~nm}$, luminescence characteristic of Sm (III) transition these transitions are assigned to ${ }^{4} \mathrm{G}_{5 / 2} \rightarrow{ }^{6} \mathrm{H}_{5 / 2}$ $(617 \mathrm{~nm})$ transitions ${ }^{35-42}$

The intense broadband that corresponding to the excitation of the organic chromophore $\left(\mathrm{S}_{\mathrm{a}} \rightarrow \mathrm{S}_{1}\right)$ transition. The emission spectrum of praseodymium $\mathbf{b}$ and neodymium $\mathbf{c}$ complexes displays two luminescence bands $\pi \rightarrow \pi^{*}$ at 364 , 619 and $622 \mathrm{~nm}$ corresponding to the ${ }^{3} \mathrm{P}_{0} \rightarrow{ }^{3} \mathrm{~F}_{2}$ for $\operatorname{Pr}(\mathrm{III})$ and ${ }^{4} \mathrm{I}_{9 / 2} \rightarrow{ }^{4} \mathrm{G}_{5 / 2}$ for $\mathrm{Nd}(\mathrm{III})$ transition respectively. The intensity sequence of the peaks is $\mathrm{I}_{419 / 2 \rightarrow 4 \mathrm{G} 5 / 2}$ $\mathrm{I}_{3 \mathrm{P} 0 \rightarrow 3 \mathrm{~F} 2}$ transition, respectively ${ }^{42}$.

$\mathrm{H}_{2} \mathrm{~L}$ is a good organic ligand that can absorb and transfer energy intramolecular from the triplet state of the ligand $\mathrm{H}_{2} \mathrm{~L}$ to excited state of the $\mathrm{Ln}(\mathrm{III})$ ions. At the same time the energy gap between the triplet state of the ligand and the emitting level of the Ln(III) ions only favors the energy transfer process for $\mathrm{Eu}(\mathrm{III}), \mathrm{Sm}(\mathrm{III}), \mathrm{Nd}(\mathrm{III})$ and $\mathrm{Pr}(\mathrm{III})$ ions $^{43-45}$. Although

different paths have been suggested for the energy transfer from $T_{t}$ to the resonance state of $\operatorname{Ln}(\mathrm{III})$ ions in lanthanide complexes. The favorite mechanism involves strong absorption of UV energy that excites the ligand to the exited singlet state $\left(\mathrm{S}_{\mathrm{t}}\right)$, followed by an energy migration via non-radiative intersystem crossing to the $T_{L}$. The energy is then transferred intermolecularly from the $T_{t}$ to a resonance state of the $\operatorname{Ln}(\mathrm{III})$ ion, from which the luminescence in the visible region occurs. To luminescence, the $T_{1}$ level must be nearly equal or lie above the resonance energy level of the $\operatorname{Ln}(\mathrm{III})$ ions. If the energy gap between the $T_{L}$ and the lowest resonance energy level of the $\operatorname{Ln}(\mathrm{III})$ ion is low then the back transfer from the lanthanide ion to the ligand can occur which reduces the intensity of the luminescence. Our results of the luminescence experiments were consistent with the proposed mechanism for intermolecular energy transfer ${ }^{46,49}$.

For the case of $\mathrm{La}(\mathrm{III})$ has no $4 \mathrm{f}$ electron and no excited states below the $T_{L}$, which is much higher in energy than the $S_{L}$ and $T_{L}$ of the ligands. Therefore, the energy absorbed by the ligand cannot be transferred to either $\mathrm{La}$ (III) ion by an intermolecular energy transfer process, however relaxes through its own lower energy levels. Therefore the emission bands observed in the emission 
spectra of $\mathrm{La}(\mathrm{III})$ complex at $363 \mathrm{~nm}$ respectively, are due to the fluorescence of the ligand. The red shift in the fluorescence band of the ligand in $\operatorname{Ln}(\mathrm{III})$ complexes compared with the free ligand can be attributed to coordination of $\mathrm{Ln}(\mathrm{III})$ ions to the ligand. This results in increasing of the delocalization of electrons and reducing the energy gaps between the molecular orbitals of the ligand ${ }^{50}$. The luminescence intensities of Eu(III),Sm(III) complexes show strong luminescence than the $\mathrm{Nd}$ (III), $\operatorname{Pr}(\mathrm{III})$ systems, which indicates that the triplet state energy is more suitable for the luminescence of $\mathrm{Eu}(\mathrm{III})$ ion than $\mathrm{Sm}(\mathrm{III})$ ion.
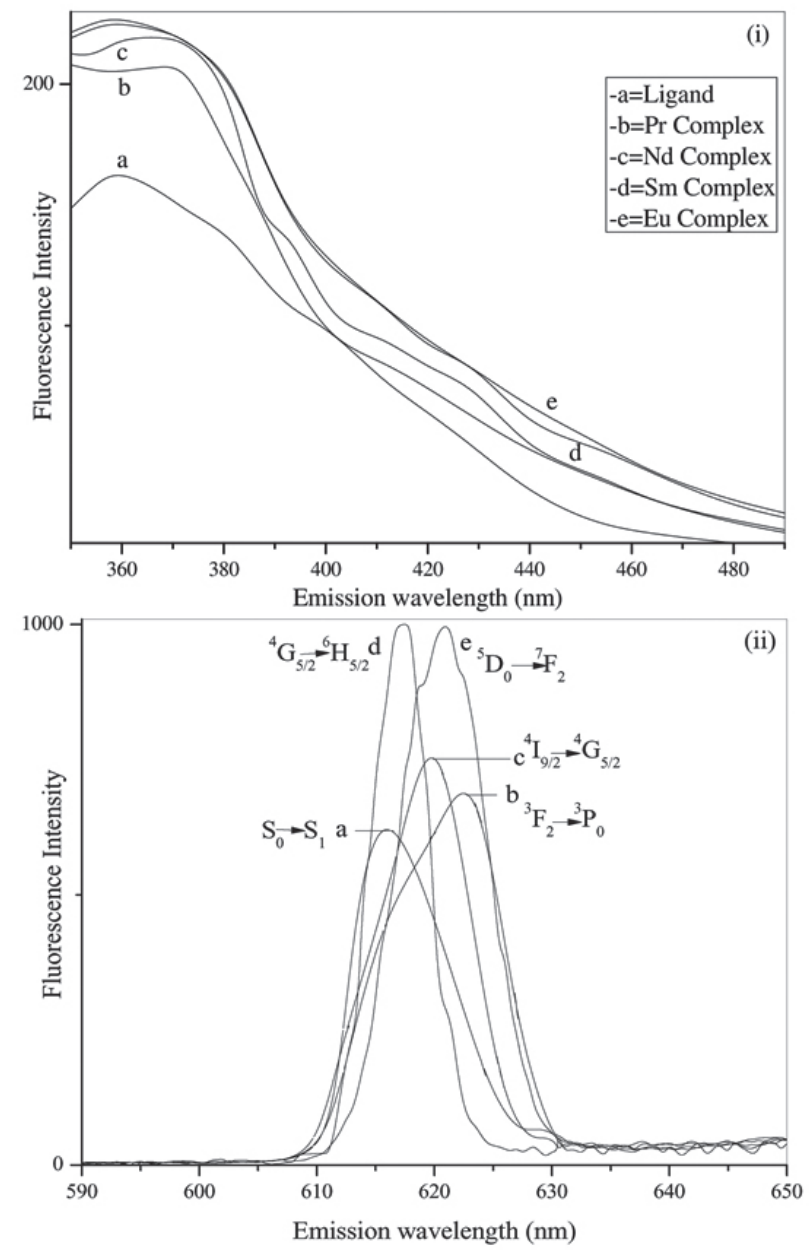

Fig.6. Fluorescence spectrum excited and emission for the $\mathrm{Ln}$ complexes (i and ii).

Table 3. Luminescence data for the Ln complexes.

\begin{tabular}{|c|c|c|c|c|c|}
\hline Compound & $\lambda_{\mathrm{ex}}(\mathrm{nm})$ & $v\left(\mathrm{~cm}^{-1}\right)$ & $\lambda_{\mathrm{em}}(\mathrm{nm})$ & $v\left(\mathrm{~cm}^{-1}\right)$ & Assignment \\
\hline Ligand $\mathrm{H}_{2} \mathrm{~L}$ & 305 & 32,786 & $\begin{array}{l}\text { 363(broad) } \\
615 \text { (broad) }\end{array}$ & $\begin{array}{l}27,548 \\
16,260\end{array}$ & $\begin{array}{l}\pi \rightarrow \pi^{*} \\
\mathrm{~S}_{0} \rightarrow \mathrm{S}_{1}\end{array}$ \\
\hline$\left[\mathrm{LaH}_{2} \mathrm{~L}\left(\mathrm{NO}_{3}\right)_{2} 2 \mathrm{H}_{2} \mathrm{O}\right] \mathrm{NO}_{3} \cdot 2 \mathrm{H}_{2} \mathrm{O}$ & 307 & 32,573 & 363(broad) & 27,548 & $\pi \rightarrow \pi^{*}$ \\
\hline$\left[\mathrm{PrH}_{2} \mathrm{~L}\left(\mathrm{NO}_{3}\right)_{2} 2 \mathrm{H}_{2} \mathrm{O}\right] \mathrm{NO}_{3} .2 \mathrm{H}_{2} \mathrm{O}$ & 307 & 32,573 & $\begin{array}{l}\text { 364(broad) } \\
622 \text { (broad) }\end{array}$ & $\begin{array}{l}27,472 \\
16,077\end{array}$ & $\begin{array}{c}\pi \rightarrow \pi^{*} \\
{ }^{3} \mathrm{~F}_{2} \rightarrow{ }^{3} \mathrm{P}_{0}\end{array}$ \\
\hline$\left[\mathrm{NdH}_{2} \mathrm{~L}\left(\mathrm{NO}_{3}\right)_{2} 2 \mathrm{H}_{2} \mathrm{O}\right] \mathrm{NO}_{3} \cdot 2 \mathrm{H}_{2} \mathrm{O}$ & 307 & 32,573 & $\begin{array}{l}\text { 364(broad) } \\
619 \text { (broad) }\end{array}$ & $\begin{array}{l}27,472 \\
16,155\end{array}$ & $\begin{array}{c}\pi \rightarrow \pi^{*} \\
{ }^{4} \mathrm{I}_{9 / 2} \rightarrow{ }^{4} \mathrm{G}_{5 / 2}\end{array}$ \\
\hline$\left[\mathrm{SmH}_{2} \mathrm{~L}\left(\mathrm{NO}_{3}\right)_{2} 2 \mathrm{H}_{2} \mathrm{O}\right] \mathrm{NO}_{3} \cdot 2 \mathrm{H}_{2} \mathrm{O}$ & 307 & 32,573 & $\begin{array}{l}\text { 363(broad) } \\
617 \text { (sharp) }\end{array}$ & $\begin{array}{l}27,548 \\
16,207\end{array}$ & $\begin{array}{c}\pi \rightarrow \pi^{*} \\
{ }^{4} \mathrm{G}_{5 / 2} \rightarrow{ }^{6} \mathrm{H}_{5 / 2}\end{array}$ \\
\hline$\left[\mathrm{EuH}_{2} \mathrm{~L}\left(\mathrm{NO}_{3}\right)_{2} 2 \mathrm{H}_{2} \mathrm{O}\right] \mathrm{NO}_{3} \cdot 2 \mathrm{H}_{2} \mathrm{O}$ & 307 & 32,573 & $\begin{array}{l}\text { 364(broad) } \\
619 \text { (sharp) }\end{array}$ & $\begin{array}{l}27,472 \\
16,155\end{array}$ & $\begin{array}{c}\pi \rightarrow \pi^{*} \\
{ }^{5} \mathrm{D}_{0} \rightarrow{ }^{7} \mathrm{~F}_{2}\end{array}$ \\
\hline
\end{tabular}

${ }^{\text {aBoard; }}{ }^{\text {bSharp }}$ 
Table 4. Electronic absorption data upon addition of CT-DNA to the Ln complexes.

\begin{tabular}{|c|c|c|c|c|c|c|}
\hline Complex & Composition & $\lambda(\max )$ & & $\Delta \lambda(\mathrm{nm})$ & $\mathrm{H}(\%)^{\mathrm{b}}$ & $K_{\mathrm{b}}\left(\mathrm{M}^{-1}\right)$ \\
\hline & (Metal : Ligand) $^{\mathrm{a}}$ & Free & Bound & & & \\
\hline$\left[\mathrm{LaH}_{2} \mathrm{~L}\left(\mathrm{NO}_{3}\right)_{2} 2 \mathrm{H}_{2} \mathrm{O}\right] \mathrm{NO}_{3} \cdot 2 \mathrm{H}_{2} \mathrm{O}$ & $1: 1$ & 398 & 395 & 3 & +18.02 & $8.2 \times 10^{5}$ \\
\hline$\left[\mathrm{PrH}_{2} \mathrm{~L}\left(\mathrm{NO}_{3}\right)_{2} 2 \mathrm{H}_{2} \mathrm{O}\right] \mathrm{NO}_{3} \cdot 2 \mathrm{H}_{2} \mathrm{O}$ & $1: 1$ & 398 & 396 & 2 & +09.99 & $1.3 \times 10^{5}$ \\
\hline$\left[\mathrm{NdH}_{2} \mathrm{~L}\left(\mathrm{NO}_{3}\right)_{2} 2 \mathrm{H}_{2} \mathrm{O}\right] \mathrm{NO}_{3} \cdot 2 \mathrm{H}_{2} \mathrm{O}$ & $1: 1$ & 398 & 396 & 2 & +19.20 & $7.4 \times 10^{5}$ \\
\hline$\left[\mathrm{SmH}_{2} \mathrm{~L}\left(\mathrm{NO}_{3}\right)_{2} 2 \mathrm{H}_{2} \mathrm{O}\right] \mathrm{NO}_{3} \cdot 2 \mathrm{H}_{2} \mathrm{O}$ & $1: 1$ & 398 & 394 & 4 & +15.78 & $2.7 \times 10^{5}$ \\
\hline$\left[\mathrm{EuH}_{2} \mathrm{~L}\left(\mathrm{NO}_{3}\right)_{2} 2 \mathrm{H}_{2} \mathrm{O}\right] \mathrm{NO}_{3} \cdot 2 \mathrm{H}_{2} \mathrm{O}$ & $1: 1$ & 398 & 395 & 3 & +17.99 & $5.3 \times 10^{5}$ \\
\hline
\end{tabular}

${ }^{\mathrm{a} O r g a n i c ~ l i g a n d ~} \mathrm{H}_{2} \mathrm{~L} ;{ }^{\mathrm{b}} \mathrm{H} \%=A_{\text {free }}-A_{\text {bound }} / A_{\text {free }} \times 100$

\subsection{DNA binding studies}

The interaction of lanthanide complexes with CT-DNA was investigated using absorption spectroscopy. The electronic spectra of $\left[\mathrm{NdH}_{2} \mathrm{~L}\left(\mathrm{NO}_{3}\right)_{2} 2 \mathrm{H}_{2} \mathrm{O}\right]$ $\mathrm{NO}_{3} \cdot 2 \mathrm{H}_{2} \mathrm{O}$ in the absence and presence of CT-DNA binding plot are given in (Supplementary Fig.S3). In the presences of increasing amount of CT-DNA, the $\left[\mathrm{NdH}_{2} \mathrm{~L}\left(\mathrm{NO}_{3}\right)_{2} 2 \mathrm{H}_{2} \mathrm{O}\right] \mathrm{NO}_{3} \cdot 2 \mathrm{H}_{2} \mathrm{O}$ complex showed an decrease in intensity [hypo chromicity $(19.20 \pm 0.5 \%)$ and hypsochromic shifts [maximum $(2 \pm 1)$ $\mathrm{nm}$ ] for their blue shift absorption maxima. The value of $K_{\mathrm{b}}$ evaluated for the complex using Eq. 1 is found to be $7.4 \times 10^{5} \mathrm{M}^{-1}$. On addition of CT-DNA to the $\mathrm{Ln}$ (III) complexes, there is decreasing in molar absorptivity as well as a significant shift in $\lambda_{\max }$. The decrease in absorption intensity and significant shift in wavelength is attributed to hypo chromism (red shift) and hypso chromism (blue shift), which suggests that the complex is bound to CT-DNA strongly. During these titrations, the change in the absorption values with increasing amount of CT-DNA was used to evaluate the intrinsic binding constants $\left(K_{\mathrm{b}}\right)$ for the complexes. The values of $K$ evaluated for the complexes using equation 1. Data are presented in (Table 4). This may be attributed to the presence of a phenyl ring in the ligand that facilitates. Therefore, the complexes may be regarded as efficient intercalators of DNA ${ }^{51-53}$.

\section{CONCLUSIONS}

A pentdentate Schiff base ligand $\mathrm{H}_{2} \mathrm{~L}$ and its lanthanide complexes $\left[\mathrm{LnH}_{2} \mathrm{~L}\left(\mathrm{NO}_{3}\right)_{2} 2 \mathrm{H}_{2} \mathrm{O}\right] \mathrm{NO}_{3} \cdot 2 \mathrm{H}_{2} \mathrm{O}$ (where, $\mathrm{Ln}=\mathrm{La}, \mathrm{Pr}, \mathrm{Nd}, \mathrm{Sm}$ and Eu were synthesized and characterized. Under UV light excitation, the $\mathrm{Pr}^{3+}, \mathrm{Nd}^{3+}, \mathrm{Sm}^{3+}$ and $\mathrm{Eu}^{3+}$ complex exhibits characteristic luminescence of trivalent metal ions, which indicates that the ligand is a good organic chelator to absorb and transfer energy to metal ions. The complex constructed by a $\mathrm{N}_{3} \mathrm{O}_{2}$ chromophore, constituted by two imine nitrogen atoms and one secondary nitrogen atom from the amine part and two phenolic hydroxyl groups. Two nitrate ion acts as bindentate ligands. In addition, the participation of two water molecules in the coordinate Ln(III) complexes [with a coordination number of 11]. The energy gap between the lowest triplet state level of the Schiff base and lowest exited state level of $\mathrm{Pr}^{3+}, \mathrm{Nd}^{3+}, \mathrm{Sm}^{3+}$ and $\mathrm{Eu}^{3+}$ favor to the energy transfer process for Ln(III) complexes. The intrinsic DNA binding constants $\left(K_{b}\right)$ of these complexes $\left(10^{5}\right)$ are quite high. Therefore, the complexes may be regarded as efficient intercalators of DNA.

\section{ACKNOWLEDGEMENTS}

The authors Dr.S.V.B are thankful to UGC, New Delhi for award of PostDoctoral Research Fellowship F.31-11(SC)/2009(SA-III). Authors also thank SSSIHL Deemed University, Puttaparthy for providing fluorescence spectral data.

\section{REFERENCES}

1. M. Irfanullah, K. Iftikhar, J. Lumin., 130,1983 (2010).

2. H.K.Kim, S.G. Roh, K.S.Hong, J. W.Ka, N.S.Baek, J.B. Oh, M.K.Ah, Y.H. Cha Ko J Macromol.Res.,11, 133(2003).

3. S.Lis, M. Elbanowski, B.Mąkowska, Z.Hnatejko, Photo Chem. Photobiol. A: Chem., 150, 233 (2002).

4. S.G.Roh, N.S.Baek, K.S. Hong, H.K.Kim, Bull. Korean Chem. Soc., 25, 343(2004).

5. A.M.Reynolds, B.R.Sculimbrene, B.Imperiali, Bioconjugate Chem., 19,588(2008).

6. J. Kido, Y. Okamoto. Chem. Rev., 102, 2357 (2002).
7. J.C.Frias, G.Bobba, M.J.Cann, C.J.Hutchisonm, D.Parker, Org. Biomol. Chem., 1, 905 (2003).

8. M.A.Diaz-Garc' ia, S.Fernandez De'Avila,M.G. Kuzyk, Appl. Phys.Lett. 81,3924(2002)

9. J.P Duan,P.P. Sun, C.H.J.Cheng, J. Mater. Online., 1, 3926 (2005)

10. G.A.Crosby, R.E.Whan, J..J.Freeman, J. Phys. Chem., 66, 2493(1962).

11. J.Feng, H.-J.Zhang, S.-Y.Song, Z.-F.Li, L.-N.Sun, Y.Xing, X.-MGuo, J. Lumin., 128, 1957(2008).

12. V.W.W.Yam, K.K.-W.Lo, Coord. Chem. Rev., 184, 157 (1998).

13. S.Dang, L.-N.Sun, S.-Y.Song, H.-J.Zhang, G.-L.Zheng, Y.-F.Bi, H.-D. Guo, Z.-YGuo, J.Feng, Inorg. Chem. Commun., 11, 531(2008).

14. Y.C.Liu, Z.Y.Yang, J. Organomet. Chem., 694, 3091 (2009).

15. J.C.G.Bünzli, Chem. Rev., 110, 2729(2010).

16. S. Kondaiah, G. Naga Raja Reddy, D. Rajesh, Jacob Joseph, Ind. J. $A d v$. Chem. Sci., 1, 228 (2013).

17. N.E. Eltayeb, S.G. Teoh, R. Adnan, J.B, Teh, H.K. Fun. J. Fluoresc., 21, 1393 (2011).

18. S. Vidyasagar Babu, K. Hussain Reddy, Ind. J. Adv. Chem. Sci.,1, 105(2013).

19. S. Vidyasagar Babu, K. Hussain Reddy, J. Indian Chem.Soci.,93, 269 (2016).

20. F.J.Welcher,The Ananlytical Use of EDTA 4, Van Nostrand, New York, (1965).

21. J. Marmur, J. Mol. Biol., 3, 208 (1961).

22. M.E.Reichman, S.A.Rice, C.A.Thomas, P. Doty, J. Am. Chem. Soc.,76, 3047 (1954).

23. A. Wolfe, G.H. Shimer, T.Meehan, Biochemistry. 26, 6392 (1987).

24. J.Chakraborty, G. Pilet, M.S.El. Fallah, J.Ribas. S.Mitra, Inorg. Chem. Commun.,10, 489 (2007).

25. Abdulaziz M. Ajlouni, Ziyad A. Taha, Khader A. Al-Hassan, Abdullah M. Abu Anzeh, J. Lumin., 132, ( 2012)1357.

26. W.J.Geary, Coord. Chem. Rev., 7, 81 (1971).

27. J.Chakraborty, A.Ray, G.Pilet, G.Chastanet, D.Luneau, R.F.Ziessel,L.J.Charbonniere, L.Carrella, E. Rentschler, M.S.El Fallah,S. Mitra, Dalton Trans., 10263 (2009).

28. X.-H.Bu, M.Du, L.Zhang, X.-B.Song, R.-H. Zhang,T.Clifford, Inorg Chim. Acta., 308, 143 (2000).

29. P.H.Lin, T.J.Burchell, R.Clerac,M.Murugesu,Angew.Chem.,Int Ed.Engl.,47,8848 (2008). 30. L.J.Farrugia, ORTEP -3 for Windows, 2.02 J. Appl. Crysta., 30, 565 (1997).

31. R.T. Conley, Infrared Spectroscopy . Boston, (1966).

32. K.Nakamoto, Infrared and Raman Spectra of Inorganic and Coordination Compounds, John Wiley, 5th Edn. (1997).

33. S.Gourbatsis,J.C.Plakatouras,V.Nastopoulos, C.J.Cardin, N.Hadjiliadis, Inorg.Chem Commun., 2, 468 (1999).

34. W.Carnall, S.Siegel, J.Ferrano, B.Tani, E.Gebert, Inorg. Chem., 12, 560 (1973).

35. O.A.Gansow, E. Loeffler, R. Davis, M. Lenkinski, R.Wilcott,J.Am.Chem. Soc., 98, 4247 (1976).

36. L.Guo, S.Wu, F.Zeng, J.Zhao, Eur. Polym. J., 42, 1670 (2006).

37. R.C.Felicio, E.T.G.Canalheiro, E.R.Dockalm, Polyhedron. 20 ,261(2001).

38. S.Zolezzi,A.Decinti, E.Spodine, Polyhedron.18, 897 (1999).

39. B.El-Sayed, M. Abo- Aly, A.Emara, S.Khalil, Vibra, Spect., 30, 93 (2002).

40. K. Binnemans, Y.Galyametdinov, R.Van-Deun, D. Bruce, S.Collinson, A.Polishchuk, J.Am. Chem. Soc., 122, 4335 (2000).

41. S.Qiang, Chemistry of Rare Earths (in Chinese), Henan Technology \& Science Press, Zhengzhou. 304 (1993). 
42. W.N. Wua, N.Tang, L.Yan, Spectrochimi. Acta Part A. 71, 1461 (2008).

43. S.Zolezzi, A.Decinti, E. Spodine, Polyhedron. 18, 897 (1999).

44. M.Latva, H.Takalo, V.M.Mukkala,C.Matachescu, C.J.Rodriguez- Ubis,J. Kankare, J. Lumin., 75 (1997)

45. F.Gutierrez, C.Tedeschi,L.Maron, J.P.Daudey, R.Poteau, J.Azema, P.Tisnes, C.J.Picard, Dalton Trans., 9, 1334 (2004).

46. Z.A.Taha, A.M.Ajlouni, K.A.Al-Hassan, A. K. Hijazi, A.B. Faig, Spectrochim. Acta, Part A.,81, 317 (2011).

47. S.J.Dunne, L.A.Summers, E.I.V. Nagy-Felsobuki, J. Heterocycl. Chem.,29, 851(1992).
48. A.M.Ajlouni, Z.A.Taha, K.A.Al-Hassan, A.M.Abu Anzeh,J. Lumine.,132, 1357(2012).

49. A.M.Ajlouni, Z.A.Taha, Z. Al Momani, A.K.Hijazi, M.Ebqaai, Inorg. Chimi. Acta. 388, 111 (2012)

50. J.X. Li, Z.X.Du, J.Zhou, H.Q.An, S.R.Wang,B.L. Zhu, S.M.Zhang, S.H.Wu,W.P. Huang, Inorg. Chim. Acta., 362, 4884 (2009).

51. P. Kapoor, R.V. Singh, N. Fahmi, J. Coord. Chem., 65, 262 (2012).

52. M.F. Wang, Z.-Y. Yang, Z.C. Liu, Y. Li, T.R. Li, M.H. Yan, X.Y. Cheng, J. Coord. Chem., 65, 3805 (2012).

53. Y.C. Liu, K.J. Zhang, R.X. Lei, J.N. Liu, T.L. Zhou, Z.Y. Yang, Jcoord Chem., 65, 2041 (2012). 